\title{
Determinants of Hong Kong's Housing Prices
}

\author{
Arnold C. S. Cheng and Michael K. Fung
}

\begin{abstract}
The objective of this study is to study the determinants of Hong Kong's housing prices. Empirical results from this study suggest that Hong Kong's housing prices are (1) positively related to per-capita GDP; (2) positively related to Hong Kong's export; (3) negatively related to departure of Hong Kong's residents; (4) negatively related the total inward and outward movements of goods vehicles; (5) positively related to commercial property prices; and (6) negatively related to factory prices.
\end{abstract}

Index Terms-Consumption, GDP, Hong Kong, housing prices.

\section{INTRODUCTION}

The objective of this study is to study the determinants of Hong Kong's housing prices. From a macroeconomic point of view, the housing sector is an important aspect of many economies, especially for the small economies with high density of population. In recent years, about $26 \%$ of all domestic investment in Hong Kong went into the private construction sector. Moreover, the relationship between housing price and household consumption has received special attention as housing assets play a prominent role in household portfolios, and consumption used to be the largest component in GDP. In Hong Kong, private consumption accounted for about $60 \%$ of total GDP. Consumption has been a major component in most macroeconomic models. Past research findings have shown that consumption is more predictable than that implied by the permanent income hypothesis [Patterson and Sowell [1], Viard [2] and Hatzinikolaou [3]. The life-cycle theory of consumption indicates that consumers' expenditure depends on human capital and the value of financial and tangible assets [Deaton [4]. The performance of the housing market has a major impact on the overall performance of the economy.

Until recently, relatively few studies have been done on the role of assets and asset prices in shaping the pattern of consumption. Housing has spending consequence which is quite different from financial assets as housing services enter the households' utility function. A number of research have been done on the Hong Kong housing market whereas the focuses are on the determination of housing prices instead of a on a macroeconomic issue. Chow and Shih [5] reported that the sustained price surge in the Hong Kong housing market is due to long-term inflation and low interest rates. The research of Mok, Chan and Cho [6] showed the effects of various housing attributes on property values. The empirical findings from Cheung, Tsang and Mak [7] imply a serial

Manuscript received October 10, 2013; revised December 20, 2013.

Arnold C. S. Cheng is with the Hong Kong Polytechnic University, Hong Kong (e-mail: afacheng@polyu.edu.hk). correlation between rental rate changes and housing price changes. Cheng and Fung [8] showed that the government policy of land supply aiming to stimulate the economy should strike a balance between the possible wealth and price effects of the housing market.

\section{DATA}

The dataset of this study includes the following variables in three categories:

Price indices:

- $\quad$ Private domestic housing property price index (PP).

- $\quad$ Private Office property price index (OP).

- $\quad$ Private Retail property price index (RP).

- $\quad$ Private Factory property price index (FP).

- Sources: The Hong Kong Rating and Valuation Department.

Sample period: 1979-2009.

Local economic indicators:

- Population (POP) in thousands persons.

- Real GDP (GDP) in million HK dollars.

- $\quad$ Per-capita real GDP (PCGDP) = GDP/POP.

- Domestic export (DX) in million HK dollars.

- $\quad$ Re-export (RX) in million HK dollars.

- Import (IM) in million HK dollars.

Sources: The Hong Kong Census and Statistics Department.

Sample period: 1979-2009.

Cross-border goods and people flows:

- Total units of inward and outward movements of goods vehicles (VEH).

- A total unit of inward and outward movements of cargos trains (TRN).

- Total number of Hong Kong resident departures (DEP).

- Total number of visitor arrivals (ARR).

Sources: Hong Kong Annual Digest of Statistics

Sample period: 1994-20

Table I provides descriptive statistics for the variables used in this study's analyses. Fig. 1-Fig. 6 show some preliminary evidence for possible relationship between Hong Kong housing price and other variables in the sample.

Fig. 1 plots PP, OP, RP and FP over the sample period, which shows that Hong Kong property prices were rather volatile, and that there was a high correlation among the prices for different types of property. A possible reason is that the prices for these different types of property are influenced by common factors such as household incomes, consumptions, investments and exports.

Fig. 2 plots PCGDP and PP over the sample period, which generally shows a positive relationship between per-capita GDP and housing price. The main reason is that higher incomes increase the demand for private housing, the 
resulting increase in housing prices in turn induce more spending and GDP growth.

TABLE I: SUMMARY STATISTICS

\begin{tabular}{|l|l|l|l|l|}
\hline Variable & Mean & Std. Dev. & Min & Max \\
\hline PP & 70.03226 & 40.47758 & 16.5 & 155 \\
\hline OP & 104.6452 & 64.41829 & 23.9 & 235.2 \\
\hline RP & 89.12258 & 56.40588 & 17.2 & 189.5 \\
\hline FP & 119.8 & 61.22136 & 40.5 & 226.8 \\
\hline POP & 6087.052 & 655.9888 & 4929.7 & 7003.7 \\
\hline GDP & 972014.3 & 384157.5 & 378972 & 1675315 \\
\hline DX & 37395.39 & 20779.25 & 603 & 63867 \\
\hline IM & 500699.3 & 426638.3 & 15130 & 1410735 \\
\hline RX & 405523.1 & 415204 & 1315 & 1335687 \\
\hline VEH & 9009543 & 706996.6 & 7794167 & 9882624 \\
\hline TRN & 28262.4 & 19006.9 & 5500 & 69403 \\
\hline DEP & $5.81 \mathrm{E}+07$ & $1.65 \mathrm{E}+07$ & $3.26 \mathrm{E}+07$ & $8.19 \mathrm{E}+07$ \\
\hline ARR & $1.67 \mathrm{E}+07$ & 7047647 & 9331156 & $2.95 \mathrm{E}+07$ \\
\hline
\end{tabular}

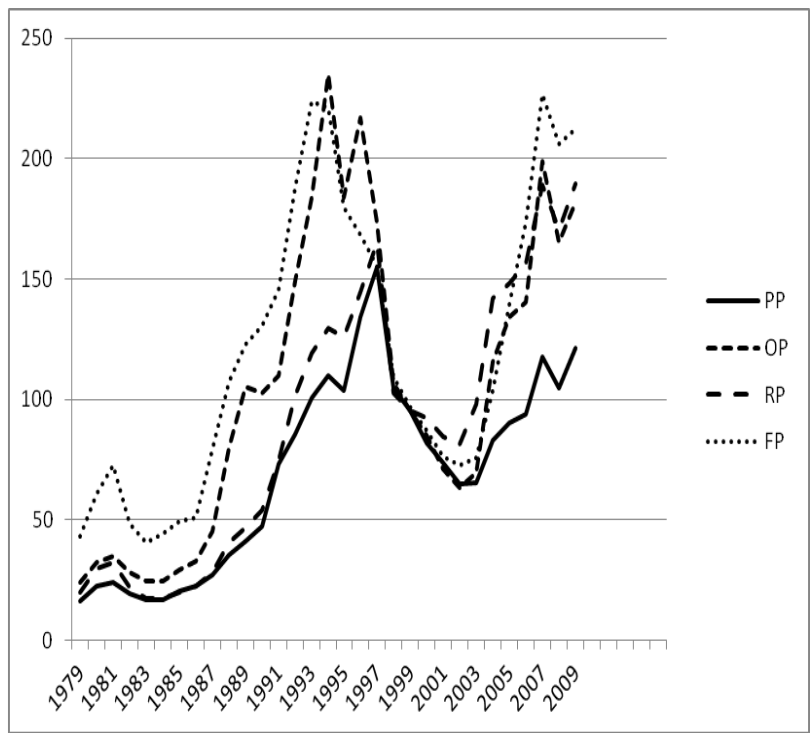

Fig. 1. Hong Kong property prices.

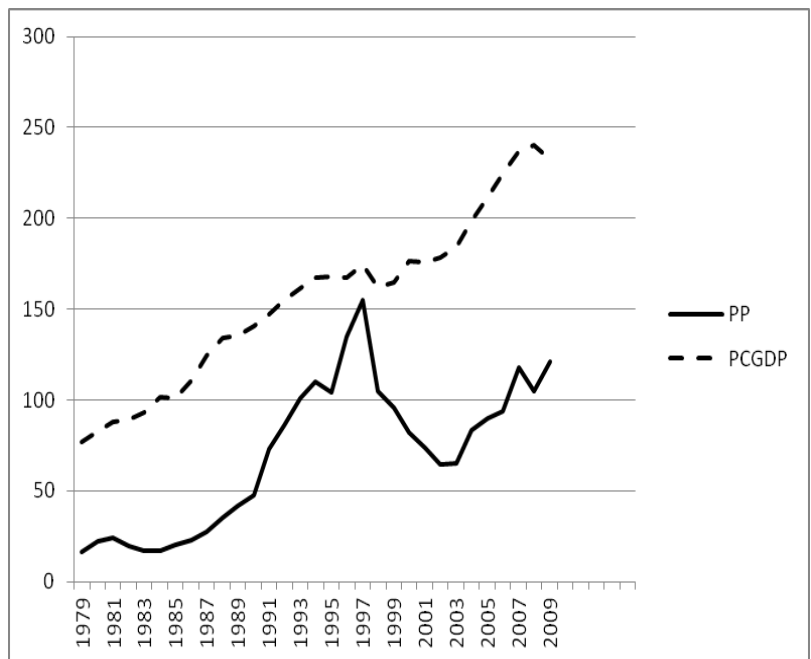

Fig. 2. Per-capita GDP and housing price

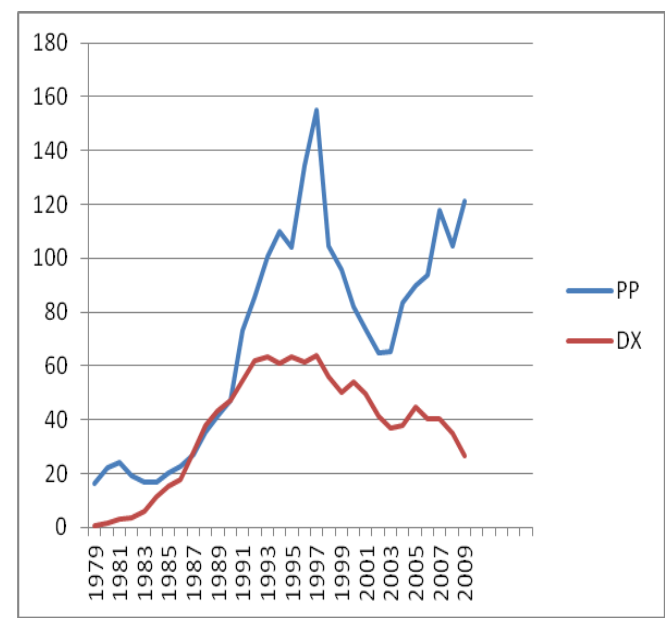

Fig. 3. Re-export and housing price.

Fig. 3 plots RX and PP over the sample period, which roughly shows a positive relationship between re-export and housing price. The reason is that re-export (from the Mainland China to the rest of the world) is traditionally a very important economic sector in Hong Kong and supply a very large number of jobs to the Hong Kong labor market.

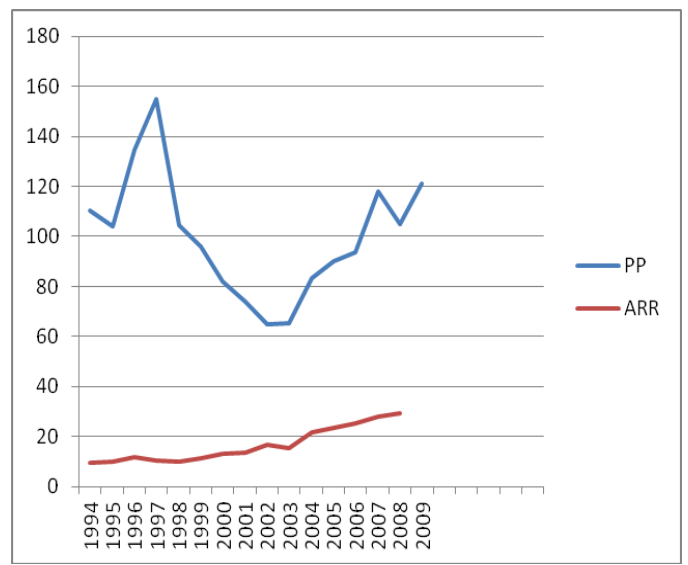

Fig. 4. Visitors' arrival and housing price.

Fig. 4 plots ARR and PP over the sample period, which does not show a clear relationship between per-capita GDP and housing price. Similarly, a clear relationship between Hong Kong resident departures (DEP) and housing price is absent in Fig. 5. The two figures seem to suggest that movement of population into and out of Hong Kong is not a major determinant of Hong Kong housing price.

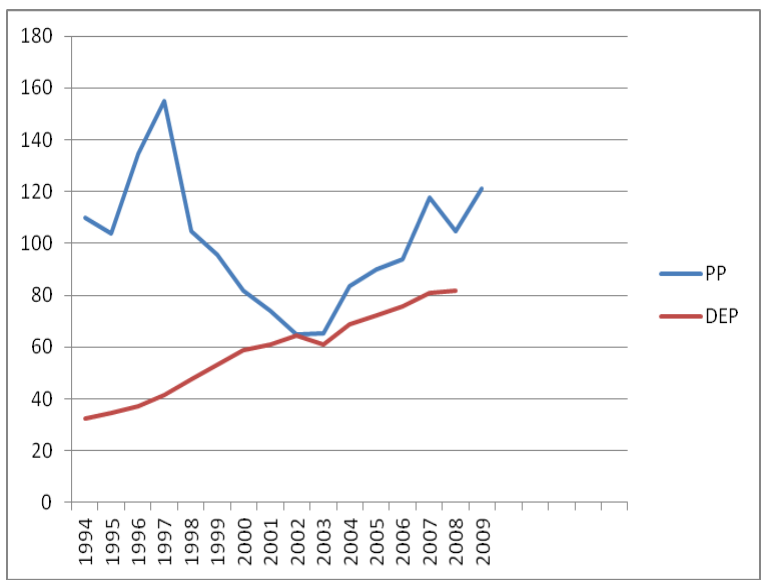

Fig. 5. Hong Kong resident departures and housing price. 
Fig. 6 plots VEH and TRN on the one hand, and Hong Kong housing price on the other. Again, the figure does not show a clear relationship between cross border cargo movement and housing price in Hong Kong.

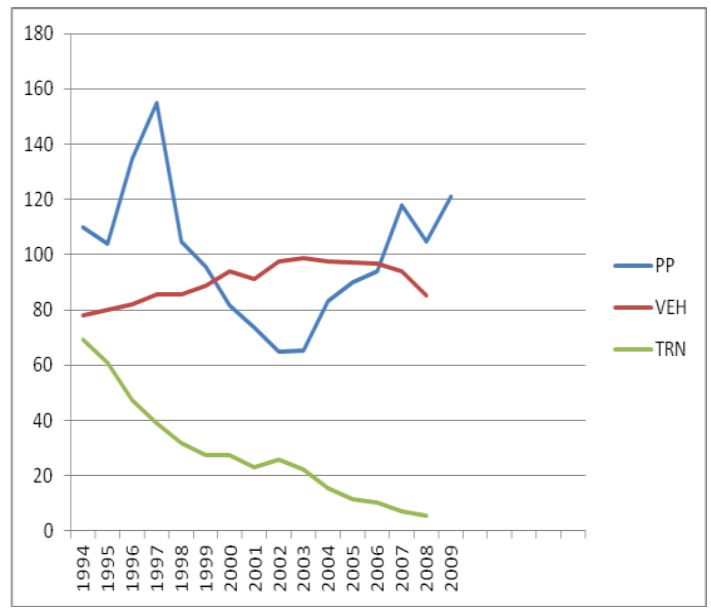

Fig. 6. Cross border cargo and housing price.

\section{RESULTS}

Regression analyses have been conducted with PP as the dependent variable. The results are reported in Table II.
Model 1 investigates the effect of per-capita GDP on housing price. Model 2 investigates the impacts of external trade flows, namely domestic export, re-export and import, on housing price. Models 3 and 4 respectively examine the effects of cross border people and goods flows on housing price. Finally, Model 5 examines the relationship between housing price and prices for other types of properties (office, retail and factory).

The significant coefficient on PCGDP in Model 1 suggests that Hong Kong's housing price is positively related to per-capita. In Model 2, while the effects of direct export and re-export on housing price are statistically significant, the effect of import is insignificant. Probably due to multicollinearity between GDP and trade, the coefficient on PCGDP becomes negative. The significantly negative coefficient on DEP in Model 3 indicates that outflow of talents have a negative effect on housing price. Results from Model 4 suggest that inward and outward movements of goods vehicles have a negative effect on housing price. Finally, results from Model 5 reveal that housing price is positively related to retail and office property prices, and is negatively related to factory property price.

TABLE II: DETERMINANTS OF HONG KONG HOUSING PRICE

\begin{tabular}{|c|c|c|c|c|c|}
\hline Independent variable & Model 1 & Model 2 & Model 3 & Model 4 & Model 5 \\
\hline PCGDP & $\begin{array}{l}0.6898 * * \\
(0.0946)\end{array}$ & $\begin{array}{l}-1.9837 * \\
(0.57710)\end{array}$ & $\begin{array}{c}1.7315 \\
(0.9835)\end{array}$ & $\begin{array}{c}0.1998 \\
(0.3335)\end{array}$ & $\begin{array}{l}-0.1099 \\
(0.1336)\end{array}$ \\
\hline $\mathrm{DX}$ & & $\begin{array}{c}0.00291 * * \\
(0.0005)\end{array}$ & & & \\
\hline IM & & $\begin{array}{l}-0.0000 \\
(0.0000)\end{array}$ & & & \\
\hline $\mathrm{RX}$ & & $\begin{array}{l}0.0002 * \\
(0.0001)\end{array}$ & & & \\
\hline DEP & & & $\begin{array}{c}-1.90 \mathrm{e}-06^{*} \\
(8.01 \mathrm{e}-07)\end{array}$ & & \\
\hline ARR & & & $\begin{array}{l}-2.93 e-06 \\
(4.73 e-06)\end{array}$ & & \\
\hline VEH & & & & $\begin{array}{l}-0.00003^{*} \\
(0.00001) \\
\end{array}$ & \\
\hline TRN & & & & $\begin{array}{l}-0.0001 \\
(0.0006)\end{array}$ & \\
\hline $\mathrm{OP}$ & & & & & $\begin{array}{c}0.4828^{* * *} \\
(0.1333)\end{array}$ \\
\hline $\mathrm{RP}$ & & & & & $\begin{array}{l}0.5598 * * \\
(0.1541) \\
\end{array}$ \\
\hline FP & & & & & $\begin{array}{c}-0.3187 * * \\
(0.1144) \\
\end{array}$ \\
\hline Constant & $\begin{array}{l}-36.9106 * \\
(15.3161)\end{array}$ & $\begin{array}{c}177.9018 * * \\
(50.7608)\end{array}$ & $\begin{array}{l}-68.9451 \\
(133.512)\end{array}$ & $\begin{array}{c}323.9036 \\
(168.7308)\end{array}$ & $\begin{array}{c}24.8346 \\
(12.3341)\end{array}$ \\
\hline Adj. R-square & 0.6347 & 0.8578 & 0.4763 & 0.3389 & 0.9165 \\
\hline
\end{tabular}

Note: Dependent variable is Private domestic housing property price index (PP). Values in parentheses are standard errors. *stands for significance at $5 \%$ level. ** stands for significance at $1 \%$ level. 
Table III explores the possibility that Hong Kong's housing price is partly determined by interactions of housing price determinants. Model 6 regresses housing price on the interaction of per-capita GDP with office property price (OP) retail property price (RP) and factory property price (FP). The results suggest that the interaction terms (except for PCGDP x OP) have significant impact on housing price. This finding implies that a high per-capita GDP strengthens the positive (negative) relationship between residential property price and retail (factory) property price. Model 7 examines whether housing price is partly determined by the interaction of between the departure of Hong Kong's residents (DEP) and movements of goods vehicles across the border (VEH). The results show that such interaction has no significant impact on housing price.

TABLE III: DETERMINANTS OF HONG KONG HOUSING PRICE WITH INTERATIONS

\begin{tabular}{|c|c|c|}
\hline Independent variable & Model 6 & Model 7 \\
\hline PCGDP & $\begin{array}{l}-0.3024 \\
(0.2840)\end{array}$ & $\begin{array}{l}1.6739 * \\
(0.6161)\end{array}$ \\
\hline PCGDP x OP & $\begin{array}{l}0.0004 \\
(0.0003) \\
\end{array}$ & \\
\hline PCGDP x RP & $\begin{array}{l}0.0001^{* *} \\
(0.0000)\end{array}$ & \\
\hline PCGDP x FP & $\begin{array}{l}-0.0002^{* *} \\
(0.0000)\end{array}$ & \\
\hline DEP & & $\begin{array}{l}7.69 \mathrm{e}-06 \\
(6.01 \mathrm{e}-06) \\
\end{array}$ \\
\hline VEH & & $\begin{array}{l}0.0000 \\
(0.0000)\end{array}$ \\
\hline DEP $x$ VEH & & $\begin{array}{l}-1.26 \mathrm{e}-12 \\
(7.91 \mathrm{e}-13)\end{array}$ \\
\hline Constant & $\begin{array}{l}34.5689 \\
(24.5961)\end{array}$ & $\begin{array}{l}-701.824 \\
(512.2049)\end{array}$ \\
\hline Adj. R-square & 0.9759 & 0.5402 \\
\hline
\end{tabular}

Note: Dependent variable is Private domestic housing property price index (PP). Values in parentheses are standard errors. *stands for significance at $5 \%$ level. $* *$ stands for significance at $1 \%$ level.

\section{CONCLUSIONS}

Preliminary empirical results from this study suggest that
Hong Kong's housing prices are 1) positively related to per-capita GDP; 2) positively related to Hong Kong's Export; 3) negatively related to departure of Hong Kong's residents; 4) negatively related to the total inward and outward movements of goods vehicles; 5) positively related to commercial property prices; and 6) negatively related to factory prices.

\section{REFERENCES}

[1] K. D. Patterson and F. Sowell, "Consumption: innovation persistence and the excess smoothness," Applied Economics, vol. 28, pp. 1245-1255, 1996.

[2] A. D. Viard, "How forecastable is consumption growth? New evidence on the Hall random walk hypothesis," Applied Economics, vol. 29, pp. 1435-1446, 1997.

[3] D. Hatzinikolaou, "Sensitivity of consumption to income and to government purchase: Some specification and estimation issues," Applied Economics, vol. 32, pp. 767-775, 2000.

[4] A. Deaton, Understanding Consumption, New York: Oxford, 1992.

[5] W. L. Chow and Y. C. Shih, "Hong Kong housing market: Overview, tenure choice, and housing demand," The Journal of Real Estate Finance and Economics, vol.10, pp. 7-21, 1995.

[6] M. K. Mok, P. K. Chan and Y. S. Cho, "A hedonic price model for private properties in Hong Kong," The Journal of Real Estate Finance and Economics, vol. 10, pp. 37-48, 1995.

[7] Y. L. Cheung, S. K. Tsang, and S. C. Mak, "The casual relationships between residential property prices and rentals in Hong Kong 1982-1991," The Journal of Real Estate Finance and Economics, vol. 10, pp. 23-35, 1995.

[8] A. C. S. Cheng and M. K. Fung, "Financial market and housing wealth effects on consumption: a permanent income approach," Applied Economics, vol. 40, pp. 3029-3038, 2008.

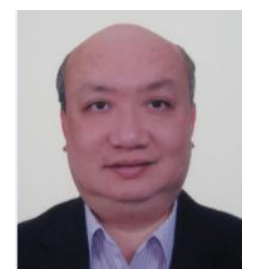

Arnold C. S. Cheng received his Ph.D. from the London School of Economics. After lecturing at the University of Liverpool for a number of years, he joined the Hong Kong Polytechnic University in 1999. Arnold Cheng began his career with research interests in international arbitrage pricing theory and international financial market movements; and in recent years, he has extended his research interests in convergence of housing prices, financial innovation and Hong Kong banking industry, housing, financial markets and the wider economy. His works have been published in refereed academic journals and in international conferences.

Michael K. Fung has published widely in areas of innovation, banking and finance, efficiency and productivity, cargo handling, and financial development. His research interests cover several economics disciplines including industrial organization, maritime economics, financial economics and econometrics 